DOI:10.17951/k.2016.23.2.9

\begin{tabular}{lcc}
\hline \multicolumn{1}{c}{ A N N A L E S } \\
UNIVERSITATIS & MARIAE CURIE-SKŁODOWSKA \\
LUBLIN - POLONIA & \\
VOL. XXIII, 2 & SECTIOK K \\
\hline
\end{tabular}

Wydział Politologii Uniwersytetu Marii Curie-Skłodowskiej w Lublinie

BARTOSZ JANIK

\title{
Partnerstwo strategiczne Gruzji ze Stanami Zjednoczonymi Ameryki w latach 1992-2009
}

Strategic partnership between Georgia and the United States of America in 1992-2009

\begin{abstract}
ABSTRAKT
W artykule przedstawiono relacje Gruzji ze Stanami Zjednoczonymi Ameryki w latach 1992-2009. Ramy czasowe nie zostały wybrane przypadkowo i odnoszą się do daty nawiązania relacji bilateralnych między państwami 23 kwietnia 1992 roku oraz podpisania umowy o partnerstwie strategicznym 9 stycznia 2009 roku. Zainteresowanie Stanów Zjednoczonych Ameryki Gruzją wynikało z polityki dywersyfikacji zasobów energetycznych Morza Kaspijskiego znajdujących się w granicach Azerbejdżanu. Gruzja w planach dywersyfikacyjnych miała stanowić terytorium tranzytowe dla ropy naftowej i gazu ziemnego do Europy Zachodniej. Jej pozycję wzmacniała chęć ominięcia terytorium Federacji Rosyjskiej, a kierunek ormiański był niemożliwy z powodu azersko-ormiańskiego konfliktu o Górski Karabach. Stany Zjednoczone Ameryki wspierały dążenia Gruzji do członkostwa w Sojuszu Północnoatlantyckim oraz Unii Europejskiej, przeznaczając znaczną pomoc finansową oraz wspierając ją w reformach administracyjnych, gospodarczych oraz samorządowych.
\end{abstract}

Słowa kluczowe: Gruzja, Stany Zjednoczone Ameryki, stosunki międzynarodowe, polityka zagraniczna

\section{WSTĘP}

Według Ryszarda Stemplowskiego, partnerstwo strategiczne „to taki stosunek między państwami, który przekracza typowy dla tych państw poziom współpracy międzynarodowej z innymi państwami, nie jest jednak ani prawną pochodną członkostwa w NATO lub UE, ani międzynarodowo upodmiotowionym prawnie związkiem państw; łączy partnerów równoprawnych, jest określany specjalnym mianem (partnerstwo strategiczne, stosunki specjalne, itp.) i wyposażony w instytucję zdolną 
do wywierania wpływu na to partnerstwo" [Stemplowski 2001: 141]. Słuszne jest podkreślanie dwóch zasadniczych celów partnerstwa strategicznego: 1) pogłębianie współpracy w zakresie bezpieczeństwa, 2) współpraca na poziomie ekonomicznym. Dopełnieniem partnerstwa jest współpraca w środowisku międzynarodowym. Warto przytoczyć definicję partnerstwa strategicznego amerykańskiego badacza Stephena R. Buranta, który we wstępie do książki Stosunki polsko-ukraińskie a idea strategicznego partnerstwa stwierdził, że zasadniczym spoiwem łączącym partnerów strategicznych powinny być wspólne cele $\mathrm{w}$ dziedzinie bezpieczeństwa i polityki zagranicznej oraz wola współdziałania dla realizacji tych celów. Zakładał również, że bardzo ważnym czynnikiem nadającym sens partnerstwu strategicznemu jest lojalność wobec partnera, czyli niepodejmowanie działań mogących zaszkodzić interesem jednej ze stron [Burant 2000: 9]. Krzysztof Bałon zauważył, że treścią partnerstwa strategicznego jest współpraca nie tylko na płaszczyźnie bilateralnej, ale także wielostronnej oraz $\mathrm{w}$ ramach organizacji wielostronnych, a ich efekty widoczne są na polach działalności międzynarodowej [Bałon 2001: 413]. Przykładem partnerstwa strategicznego jest alians Gruzji i Stanów Zjednoczonych Ameryki, który stanowi zwieńczenie wieloletniej współpracy. Według umowy o partnerstwie podstawę partnerstwa strategicznego Gruzji ze Stanami Zjednoczonymi Ameryki stanowi wzajemna pomoc w budowaniu suwerenności, niepodległości, integralności terytorialnej oraz nienaruszalności granic [SI: www.state.gov]. Istotny zapis stanowi deklaracja obu państw o wspólnym stanowisku w kwestii pełnej integracji Gruzji ze strukturami europejskimi oraz transatlantyckimi w wymiarach politycznym, ekonomicznym i wojskowym. Podstawą do integracji jest wypełnienie przez Gruzję wymaganych standardów. $\mathrm{Z}$ tego zapisu wynika również, że celem partnerstwa jest pomoc w osiągnięciu potrzebnych standardów umożliwiających jej integrację ze strukturami zachodnimi.

Za początek stosunków między Gruzją a Stanami Zjednoczonymi Ameryki należy uznać ogłoszenie suwerenności przez Gruzję. Wcześniej kontekst gruziński nie istniał w polityce zagranicznej Stanów Zjednoczonych Ameryki. Stan ten był determinowany przez biegunowy podział środowiska międzynarodowego oraz zależność Gruzji od Moskwy. W amerykańskiej przestrzeni dyskurs na temat gruzińskiej historii i polityki był w zasadzie niezauważalny [McFarlane 2013: 80]. Dopiero rozpad Związku Socjalistycznych Republik Radzieckich i upadek ,żelaznej kurtyny” otworzyły możliwość nawiązania kontaktów politycznych, kulturowych oraz ekonomicznych. Istotnymi elementami w rozwoju relacji bilateralnych między Gruzją a Stanami Zjednoczonymi Ameryki była przyjęta przez rząd w Tbilisi zachodnia orientacja w polityce zagranicznej. Kluczową rolę odegrały zasoby energetyczne Morza Kaspijskiego, dla których przy założeniu wyłączenia terytorium Rosji jako korytarza transportowego Gruzja stanowiła jedyną możliwość tranzytową do Europy. Powodem, który zadecydował o wykorzystaniu terytorium gruzińskiego jako korytarza przepływu surowców naturalnych, był konflikt azersko-armeński o Górski Karabach i nieistniejące stosunki dyplomatyczne między Erewaniem a Baku, co wykluczało udział Armenii w projektach dywersyfikacji dostaw ze złóż kaspijskich. 
Celem artykułu jest ukazanie dynamiki stosunków gruzińsko-amerykańskich w latach 1992-2009 oraz czynników, które miały wpływ na ich rozwój. Realizacja owego celu będzie możliwa przez weryfikację następującej hipotezy: rozwój stosunków gruzińsko-amerykańskich, których wynikiem było podpisanie układu bilateralnego o ustanowieniu partnerstwa strategicznego, stanowił kumulację wielu czynników występujących na płaszczyźnie relacji między Gruzją a Stanami Zjednoczonymi Ameryki w omawianym przedziale czasowym. Do najistotniejszych czynników należy zaliczyć wzrost zainteresowania międzynarodowych koncernów naftowych (w tym amerykańskich) złożami energetycznymi basenu Morza Kaspijskiego, prozachodnią politykę zagraniczną Gruzji oraz potrzebę wzmocnienia wpływów w obszarze Bliskiego Wschodu i przy granicy Federacji Rosyjskiej przez USA. Aby osiągnąć wyznaczony cel, autor starał się odpowiedzieć na następujące pytania, które pomogą w zweryfikowaniu postawionej hipotezy. Po pierwsze, jaki charakter miały stosunki gruzińsko-amerykańskie w omawianym okresie? Po drugie, w jaki sposób projekty dywersyfikacyjne zasobów naturalnych Morza Kaspijskiego wpłynęły na pozycję Gruzji na arenie międzynarodowej? Po trzecie w końcu, jakie konsekwencje dla Gruzji miała współpraca ze Stanami Zjednoczonymi Ameryki?

\section{UWARUNKOWANIA PARTNERSTWA}

Partnerstwo strategicznie Stanów Zjednoczonych Ameryki z Gruzją jest bilateralnym układem, w którym zakłada się współpracę w zakresie bezpieczeństwa i obrony oraz rozwój współpracy w strukturach Sojuszu Północnoatlantyckiego. Innymi aspektami współpracy w ramach partnerstwa strategicznego pozostaje płaszczyzna ekonomiczna i energetyczna, a także wzmacnianie demokracji i wymiana kulturalna [SI: www.state.gov]. Dokument ustanawiający partnerstwo strategiczne został podpisany 9 stycznia 2009 roku w Waszyngtonie przez sekretarz stanu Stanów Zjednoczonych Ameryki Condoleezzę Rice oraz ministra spraw zagranicznych Gruzji Grigola Vashadze [SI: www.state.gov]. Instytucją sprawującą kontrolę nad funkcjonowaniem i realizacją partnerstwa jest Komisja Partnerstwa Strategicznego, która obraduje na spotkaniach roboczych odbywających się co kilka miesięcy.

Program partnerstwa strategicznego nie jest projektem unikatowym wobec Gruzji, ale programem bliźniaczym do partnerstwa strategicznego Ukraina-Stany Zjednoczone Ameryki podpisanego pod koniec 2008 roku. Inicjatywa ta była wzorowana na umowach preintegracyjnych z państwami bałtyckimi i zachodniobałkańskimi [Welt 2010: 1]. Jest przygotowaniem potencjalnych kandydatów do członkostwa w Sojuszu Północnoatlantyckim.

Partnerstwo strategiczne Gruzji ze Stanami Zjednoczonymi Ameryki stało się wypadkową dążeń stowarzyszeniowych Gruzji z Sojuszem Północnoatlantyckim oraz zainteresowania Stanów Zjednoczonych Ameryki obszarem Gruzji i jej bliskiego sąsiedztwa. Do najważniejszych uwarunkowań współpracy gruzińsko-amerykańskiej 
zaliczamy politykę zagraniczną wobec Stanów Zjednoczonych Ameryki, kreowaną przez prezydentów Eduarda Szewardnadzego i Micheila Saakaszwilego (okres prezydentury Zwiada Gamsachurdii charakteryzował się brakiem uznania międzynarodowego dla państwa), położenie geopolityczne Gruzji oraz tranzytowy charakter państwa dla transportu zasobów energetycznych z Azerbejdżanu.

Prezydentura Zwiada Gamsachurdii zakończyła się międzynarodową izolacją Gruzji. Główne cele w polityce zagranicznej jego kadencji, czyli osłabienie relacji ze Związkiem Radzieckim oraz zainicjowanie procesu integracji ze strukturami euroatlantyckimi, nie miały prawa zostać zrealizowane. Brak efektów w realizacji głównych celów w polityce zagranicznej Gamsachurdii wynikał ze stanowiska państw Zachodu, które przyjęły postawę wyczekującą na rozwój sytuacji w Związku Radzieckim. Postawa państw zachodnich oraz fobia na punkcie Federacji Rosyjskiej doprowadziły go do utraty władzy. Za rządów Gamsachurdii Gruzja nie została przyjęta do ONZ, a oprócz tego żadne europejskie państwo nie uznało jej niepodległości. Co więcej, poczynania polityków Zachodu (m.in. George'a W. Busha) Gamsachurdia nazwał „kapitulacją wobec totalitaryzmu” [Coppieters 1998: 58-59].

W wyniku odsunięcia prezydenta Gamsachurdii władzę przejął Eduard Szewardnadze - przewodniczący Komunistycznej Partii Gruzji, a następnie w latach 19851990 minister spraw zagranicznych Związku Socjalistycznych Republik Radzieckich. Autorytet Szewardnadzego miał pomóc wyjść Gruzji z problemów wewnętrznych (wojna w Abchazji doprowadziła do dezintegracji terytorialnej), ustabilizować stosunki z Rosją, a także doprowadzić do uznania międzynarodowego. Zadania powierzone Szewardnadzemu udało się osiągnąć w relatywnie krótkim czasie. W ciągu kilku miesięcy od przejęcia władzy przez Szewardnadzego Gruzja zyskała uznanie międzynarodowe najważniejszych państw europejskich oraz Stanów Zjednoczonych Ameryki.

Za początek relacji gruzińsko-amerykańskich można uznać powrót Szewardnadzego do Gruzji w marcu 1992 roku [McFarlane 2013: 81]. Były minister spraw zagranicznych Związku Radzieckiego cieszył się szacunkiem ówczesnego prezydenta Stanów Zjednoczonych Ameryki George’a W. Busha. Obu prezydentów łączyła bliska znajomość zawarta w ciągu dwóch ostatnich lat istnienia Związku Radzieckiego. Według Busha, Szewardnadze odegrał znaczną rolę w zakończeniu ,zimnej wojny”, a także doprowadził do pokojowego wycofania wojsk radzieckich z Niemieckiej Republiki Demokratycznej. Do końca 1993 roku Gruzja wstąpiła do Organizacji Narodów Zjednoczonych, Międzynarodowego Funduszu Walutowego oraz Wspólnoty Państw Morza Czarnego. Jednak w wyniku trudnej sytuacji wewnętrznej Szewardnadze był zmuszony do intensyfikacji współpracy z Rosją, co wyrażało się w przystąpieniu Gruzji do Wspólnoty Niepodległych Państw, podpisaniu Układu o Bezpieczeństwie Zbiorowym (tzw. traktat taszkencki) ${ }^{1}$, uznaniu kluczowej roli Rosji w uregulowaniu

1 Układ o Bezpieczeństwie Zbiorowym (tzw. traktat taszkencki) jest umową międzynarodową podpisaną 15 maja 1992 roku przez Rosję, Kazachstan, Armenię, Tadżykistan, Uzbekistan i Kirgistan. 
konfliktów na terenie Gruzji oraz podpisaniu umowy o stacjonowaniu wojsk rosyjskich na terenie Gruzji [Trzaskowski 2009: 130]. Podpisanie traktatu taszkenckiego wynikało ze zobowiązania Szewardnadzego wobec Rosji, której wojska pomogły zatrzymać ofensywę oddziałów obalonego prezydenta Gamsachurdii. „Zwiadziści” (potoczne określenie oddziałów zbrojnych obalonego prezydenta) w okresie od sierpnia 1993 roku do stycznia 1994 roku przejmowali kontrolę nad kolejnymi regionami Gruzji i stanowili realne zagrożenie dla wybuchu wojny [Materski 2010: 307-312].

W wyniku trudnej sytuacji wewnętrznej Gruzji w pierwszych latach od uzyskania niepodległości stosunki ze Stanami Zjednoczonymi Ameryki rozwijały się bardzo powoli. Mimo otwartych deklaracji o euroatlantyckim kursie Szewardnadze musiał brać pod uwagę silne oddziaływanie Rosji. Również priorytety Stanów Zjednoczonych Ameryki oraz Sojuszu Północnoatlantyckiego nie były zbieżne z gruzińskimi aspiracjami. Brak zbieżności interesów oraz wciąż słabe relacje pomiędzy państwami spowodowały, że Stany Zjednoczone Ameryki nie zaangażowały się w rozmowy mające na celu pokojowe rozstrzygnięcie konfliktu gruzińsko-osetyjskiego oraz gruzińsko-abchaskiego. Należy jednak wspomnieć, że owa bierność strony amerykańskiej wynikała również z akceptacji wpływów Rosji w „bliskiej zagranicy” [McFarlane 2013: 82].

W 1994 roku Szewardnadze doprowadził do przystąpienia Gruzji do programu „Partnerstwo dla Pokoju”. Wiosną tego samego roku prezydent Gruzji odbył wizytę w Waszyngtonie, gdzie rozmawiał m.in. o projekcie utworzenia ropociągu transportującego ropę naftową ze złóż kaspijskich. Po powrocie do Tbilisi oświadczył, że nie prosił o pomoc militarną. Jednak w wywiadzie dla niemieckiego pisma „Focus” stwierdził, że Rosja nie będzie w stanie zmusić Gruzji do ograniczenia kontaktów z tzw. Zachodem. W 1997 roku Gruzja dołączyła do Euroatlantyckiej Rady Partnerstwa, a w 1998 roku ustanowiono oficjalne stosunki Gruzja-Sojusz Północnoatlantycki [Cecire 2013: 67]. Również w 1997 roku Szewardnadze oświadczyl, że kurs euroatlantycki jest historycznym celem i realizacją marzeń przodków, a w 1999 roku w wywiadzie dla „Financial Times” zapowiedział, że jeżeli obywatele wybiorą go ponownie prezydentem, będzie „bardzo intensywnie pukał do drzwi NATO” [Trzaskowski 2009: 133-134].

W roku 2001 Szewardnadze doprowadził do jeszcze mocniejszego zbliżenia z Waszyngtonem. Po zamachach na World Trade Center przedstawiciele rosyjskiego rządu przekonywali, że Usama ibn Laden (domniemany szef Al Ka'idy oraz inicjator zamachów z 11 września 2001 roku) ukrywa się w Wąwozie Pankiskim (dolina w północno-wschodniej Gruzji przy granicy z Czeczenią i Dagestanem). Rządowi w Tbilisi trudno było zignorować tę sprawę. Dzięki amerykańskiej pomocy wąwóz został oczyszczony z rebeliantów.

Umowa dotyczy zacieśniania współpracy między członkami Wspólnoty Niepodległych Państw w kwestii tworzenia wspólnego systemu bezpieczeństwa zbiorowego. Gruzja przystąpiła do Układu 9 grudnia 1993 roku. 
Ostatnim ważnym wystąpieniem na arenie międzynarodowej Szewardnadzego był szczyt Sojuszu Północnoatlantyckiego w Pradze w 2002 roku. Szewardnadze w krótkim wystąpieniu zapewnił, że przyznanie Gruzji programu „Partnerstwa dla Pokoju” było dobrą decyzją. Podkreślił, że tylko odpowiednie reformy gospodarcze, polityczne, militarne i społeczne pozwolą Gruzji stać się pełnoprawnym członkiem Sojuszu. Podkreślił, że „droga” do struktur północnoatlantyckich jest wieloletnim i skomplikowanym procesem. Zaznaczył również, że każdy obywatel Gruzji z nadzieją oczekiwał szczytu Sojuszu w Pradze. Szewardnadze powiedział wówczas: „Jedyna kwestia, przeciw której nie podniesiono [w Gruzji - przyp. B.J.] w ostatnich latach żadnego rozsądnego argumentu, to przyszłość bezpieczeństwa państwa. Gruzińska opinia publiczna widzi ją w kontekście członkostwa w NATO. Jestem rad, że na szczycie Euroatlantyckiej Rady Współpracy mogę zadeklarować, że Gruzja jest zdecydowana być pełnoprawnym członkiem NATO i zdeterminowana, by ciężko pracować w celu wypełnienia tej historycznej misji [...] Gruzini przez stulecia pozostawali odcięci od cywilizacji zachodniej, choć zawsze dostrzegali w niej swe słuszne miejsce" [SI: www.nato.int]. Bardzo istotny jest fragment wypowiedzi dotyczący poczucia obywateli Gruzji do przynależności do kręgu cywilizacji zachodniej. W obliczu dominacji i wywierania wpływu na ten region przez Rosję Gruzini nie zatracili poczucia inherencji z Europą.

W roku 2003 do władzy w Gruzji doszedł Micheil Saakaszwili. W swoim inauguracyjnym przemówieniu 26 stycznia 2004 roku wskazał wprost na euroatlantycki kurs polityki zagranicznej Gruzji, a wypowiedź, w której zapewnił, że nie będzie politykiem „proamerykańskim” ani ,prorosyjskim”, tylko „progruzińskim”, została w Europie odebrana pozytywnie [SI: www.rferl.org]. Saakaszwili od początku urzędowania dał się poznać jako polityk odważny i wywiązujący się z wyborczych obietnic, czego dowodem było przywrócenie kontroli nad Adżarią, a następnie nieudana próba przejęcia kontroli nad zbuntowaną Osetią Południową w 2004 roku. Wynikiem tych działań było jednak znaczne pogorszenie kontaktów z Moskwą (chociaż początkowo w Moskwie wybór Saakaszwiliego został dobrze przyjęty), która zaczęła propagować na Zachodzie obraz rządu w Tbilisi jako awanturniczego i nacjonalistycznego [Strachota, Bartuzi 2008: 17]. Saakaszwili zdawał sobie sprawę z niebezpieczeństwa, jakie stwarzała Rosja traktująca Gruzję jako swoją strefę wpływów. Zadbał o poprawę wizerunku Gruzji na arenie międzynarodowej jako państwa prawa, szanującego i propagującego zasady demokracji, co pozwoliło nawiązać bliskie relacje z Waszyngtonem. Stany Zjednoczone Ameryki stały się „opiekunem” Gruzji i wspierały ją w drodze do struktur północnoatlantyckich. Działania Saakaszwiliego na płaszczyźnie wizerunkowej przyniosły wymierne skutki. W maju 2005 roku Gruzję odwiedził prezydent Stanów Zjednoczonych Ameryki George W. Bush. Wizyta ta nabrała wyjątkowego charakteru z uwagi, że była to pierwsza wizyta prezydenta Stanów Zjednoczonych Ameryki na Kaukazie. Administracja Busha dała wyraźny znak, że Gruzja jest ostoją demokracji i przedstawicielem Stanów Zjednoczonych Ameryki w regionie. Intensyfikacji uległy również wizyty prezydenta Gruzji w Waszyngtonie. W latach 2003-2009 pięciokrotnie odbył spotkania z prezydentem Bushem w Waszyngtonie. 
Działania Saakaszwilego na rzecz poprawy standardów demokracji w państwie zostały docenione. W 2004 roku Gruzji przyznano „Indywidualny Plan Działania na rzecz Partnerstwa". W kwietniu 2008 roku przed szczytem Sojuszu w Bukareszcie Saakaszwili silnie lobbował na rzecz uzyskania „Planu Działań na rzecz Członkostwa”. Już wtedy jego stosunki z Kremlem były bardzo złe. Nieugięta postawa prezydenta spotkała się z silną reakcją polityków rosyjskich. Dmitrij Rogozin, rosyjski ambasador przy Sojuszu Północnoatlantyckim ostrzegł, że jeżeli Sojusz Północnoatlantycki zgodzi się na członkostwo Gruzji, to dojdzie do secesji Abchazji i Osetii Południowej. Saakaszwili przekonywał zaś, że jeżeli nie dojdzie do zbliżenia Gruzji z Sojuszem, to może dojść nawet do wojny z Rosją.

Rosyjska agresja na Gruzję w sierpniu 2008 roku spotkała się z krytyką zarówno Stanów Zjednoczonych Ameryki, jak i Sojuszu Północnoatlantyckiego. Saakaszwili otrzymał pełne poparcie Waszyngtonu, a sekretarz stanu Condoleezza Rice zaangażowała się w mediację na rzecz zakończenia konfliktu. Można zaryzykować stwierdzenie, że Saakaszwili wyszedł zwycięsko z wojny z Rosją. „Układ o partnerstwie strategicznym" między Gruzją a Stanami Zjednoczonymi Ameryki miał zapobiegać w przyszłości tego typu konfliktom, jak ten z sierpnia 2008 roku. Miał on był również docenieniem starań prezydenta Gruzji o członkostwo w Sojuszu Północnoatlantyckim [SI: www.state.gov]. Mimo osłabienia relacji po wojnie z 2008 roku i zmiany amerykańskiej administracji, nadal widać, jak istotnym partnerem dla Stanów Zjednoczonych Ameryki jest Gruzja. Przykładem jest potężna inwestycja w laboratorium wykrywania chorób zakaźnych i monitoringu epidemiologicznego. Laboratorium otworzono w marcu 2011 roku. Amerykańsko-gruziński personel stanowią zarówno wojskowi, jak i cywile. Powstanie w Gruzji obiektu istotnego dla bezpieczeństwa Stanów Zjednoczonych Ameryki wzmocniło amerykańską obecność w tym kraju, o co konsekwentnie zabiegał prezydent Saakaszwili przez całą kadencję, widząc w tym sposób na wzmocnienie bezpieczeństwa państwa.

Stosowne jest postawienie pytania o znaczenie Gruzji na płaszczyźnie geopolitycznej w polityce zagranicznej Stanów Zjednoczonych Ameryki. Można wyróżnić trzy powody zaangażowania USA w polityczne dążenia Gruzji.

Po pierwsze, amerykańskie koncerny energetyczne oraz ich zagraniczni partnerzy wyrazili zainteresowanie złożami basenu Morza Kaspijskiego. Koncerny te były świadome potencjału energetycznego, jakie posiada Morze Kaspijskie, oraz rentowności tych zasobów, jednak problem polegał na sposobie wprowadzenia ich na rynek międzynarodowy [McFarlane 2013: 84]. Projekt oparty na transporcie przez terytorium Iranu został wykluczony z powodu różnic ideologicznych pomiędzy Stanami Zjednoczonymi Ameryki a Iranem (pomimo niskich kosztów realizacji projektu). Brak możliwości realizacji tego projektu wzmacniały sankcje nałożone w 1996 roku przez Kongres Stanów Zjednoczonych Ameryki na Iran i Libię². Alternatywną drogą transportową

2 Kongres Stanów Zjednoczonych Ameryki przyjął 23 lipca 1996 roku ustawę ILSA „Iran-Libya Sanctons Act" nakładającą sankcje na firmy zagraniczne, których inwestycje w sektor naftowy Iranu przekroczą 40 milionów dolarów. 
okazało się terytorium Kaukazu Południowego z portem przeładunkowym w Turcji. Z powodu nieuregulowanego konfliktu armeńsko-azerbejdżańskiego jedynym możliwym korytarzem transportowym okazała się Gruzja.

Po drugie, władze amerykańskie były świadome braku zainteresowania strony rosyjskiej rozwiązaniem konfliktów na terenie postradzieckim. W stanie ciągłego zagrożenia wybuchem wojny domowej, m.in. na terytorium Gruzji, Rosja widziała szansę realnego wpływu na politykę wewnętrzną państwa i zachowania kontroli nad państwami „bliskiej zagranicy”. Napięcie między Stanami Zjednoczonymi Ameryki a Rosją wzrosło, kiedy w 1996 roku prezydent Stanów Zjednoczonych Ameryki Bill Clinton zapowiedział rozszerzenie Sojuszu Północnoatlantyckiego o państwa Europy Środkowo-Wschodniej.

Po trzecie, w obliczu zamachów z 11 września Gruzja nabrała jeszcze większego znaczenia z powodu swojego położenia i ukształtowania terenu. Terytorium gruzińskie stanowiło bardzo dobrą lokalizację dla baz wojskowych w perspektywie przerzutu wojsk na Bliski Wschód. Gruzja w tym wypadku okazała się być lojalnym partnerem, gdyż w ciągu 48 godzin od ataków na World Trade Center zadeklarowała pomoc Stanom Zjednoczonym, proponując współpracę wywiadowczą oraz oddała do dyspozycji swoją przestrzeń powietrzną, a także bazy wojskowe.

\section{WYMIAR ENERGETYCZNY STOSUNKÓW GRUZIŃSKO-AMERYKAŃSKICH}

Oprócz polityki wobec Stanów Zjednoczonych Ameryki kreowanej przez kolejnych prezydentów Gruzji, najważniejszym czynnikiem kształtującym relacje na linii Tbilisi-Waszyngton jest transport surowców mineralnych $\mathrm{z}$ azerbejdżańskich zasobów Morza Kaspijskiego [SI: www.isn.ethz.ch].

Projekt wykorzystania zasobów kaspijskich pojawił się w połowie lat 90. XX wieku. W tym samym czasie intensywnego charakteru nabrały relacje gruzińsko-amerykańskie. Polityka dywersyfikacji zasobów znad Morza Kaspijskiego i ich transport do państw europejskich była oparta na założeniu konieczności ominięcia terytorium Rosji [McFarlane 2013: 83]. Gruzja dzięki swojemu położeniu geopolitycznemu była dobrym korytarzem transportowym dla surowców mineralnych. $Z$ tego też powodu od zagwarantowania bezpieczeństwa na terytorium Gruzji zależało powodzenie całego projektu. Należy zaznaczyć, że jednym z celów przystąpienia Gruzji do „Partnerstwa dla Pokoju" było zapewnienie bezpieczeństwa dostaw surowca do Europy.

Od 1995 roku administracja Stanów Zjednoczonych Ameryki prowadziła strategię konstrukcji wielu rurociągów mających transportować ropę kaspijską, które połączyłyby Kaukaz i Azję Centralną z rynkami światowymi przez terytorium Turcji. W 1997 roku koncepcję wielu ropociągów przekształcono we wspieranie jednego - Baku-Tbilisi-Ceyhan oraz powiązanego z nim gazociągu Baku-Tbilisi-Erzurum. Projekty te stały się kluczowymi punktami w polityce Stanów Zjednoczonych Ameryki wobec Kaukazu Południowego, w tym Gruzji. Budowa rozpoczęła się w drugiej połowie 
lat 90. XX wieku. Inwestycja ta napotkała przeszkody, m.in. na terenie Gruzji, gdzie dochodziło do ataków partyzanckich. Uruchomienie rurociągu w 2006 roku było ogromnym sukcesem nie tylko Stanów Zjednoczonych Ameryki, lecz także Gruzji. Z jednej strony Waszyngton przełamał monopol ekonomiczny Rosji w regionie Kaukazu Południowego, a z drugiej Gruzja miała możliwość wyboru partnera do współpracy.

Budowa ropociągów Baku-Tbilisi-Ceyhan oraz Baku-Tbilisi-Erzurum była znaczącym postępem dla Gruzji w integracji euroatlantyckiej. Gruzja wzmocniła swój potencjał geostrategiczny i geoekonomiczny. Wzrosła również wymiana handlowa między Gruzją a Stanami Zjednoczonymi Ameryki. Zrealizowanie tego projektu ukierunkowało politykę zagraniczną Gruzji. Gdyby nie odkrycie kaspijskich zasobów energetycznych oraz rozpad Związku Socjalistycznych Republik Radzieckich, Kaukaz Południowy i Azja Centralna pozostałyby marginalnym obszarem zainteresowania architektów amerykańskiej polityki zagranicznej [Pliszczyńska 2010: 35-37].

Tabela 1 zawiera dane ekonomiczne na temat wymiany handlowej między Gruzją a Stanami Zjednoczonymi Ameryki w latach 2000-2009 w milionach dolarów. Duży wzrost wymiany w latach 2005-2007 toczył się równocześnie z oddaniem do użytku dwóch rurociągów - Baku-Tbilisi-Ceyhan w 2005 roku oraz Baku-Tbilisi-Erzurum w 2006 roku. Spadek wymiany handlowej w roku 2008 i 2009 był spowodowany konfliktem zbrojnym między Gruzją a Rosją w sierpniu 2008 roku.

Tabela 1. Wymiana handlowa między Gruzją a Stanami Zjednoczonymi Ameryki w latach 2000-2009 w milionach dolarów

\begin{tabular}{|c|c|c|}
\hline Rok & Eksport & Import \\
\hline 2000 & 7,1 & 69,6 \\
\hline 2001 & 8,8 & 64,1 \\
\hline 2002 & 13,5 & 68,8 \\
\hline 2003 & 15,4 & 90,7 \\
\hline 2004 & 21,2 & 110,9 \\
\hline 2005 & 26,7 & 146,9 \\
\hline 2006 & 58,9 & 129,6 \\
\hline 2007 & 149,0 & 203,8 \\
\hline 2008 & 102,1 & 358,0 \\
\hline 2009 & 36,9 & 226,7 \\
\hline Suma & 439,6 & 1469,1 \\
\hline
\end{tabular}

Źródło: strona internetowa Ministerstwa Spraw Zagranicznych Gruzji, www.mfa.gov.ge, Relations Between Georgia and the United States of America (dostęp: 16.03.2014).

\section{CHARAKTER PARTNERSTWA}

Wzrost zainteresowania Stanów Zjednoczonych Ameryki obszarem Kaukazu Południowego (w tym Gruzji) był widoczny od początku lat 90. XX wieku i wynikał z chęci wzmocnienia wpływów w regionie Bliskiego Wschodu oraz przy 
granicy Federacji Rosyjskiej. Również na początku lat 90. XX wieku pojawiło się zainteresowanie wykorzystaniem zasobów ropy naftowej i gazu ziemnego z Morza Kaspijskiego [Baran 2005: 2]. Z racji że jedynym sposobem transportu surowców mineralnych jest droga lądowa, Gruzja miała pełnić rolę państwa tranzytowego. Bezpieczeństwo na jej terytorium stało się szczególnie istotne dla zagwarantowania płynności dostaw surowców [Batan 2005: 32].

Polityka Stanów Zjednoczonych Ameryki wobec Gruzji stanowi wypadkową polityki demokratyzacji obszarów postradzieckich. Już od początku lat 90 . XX wieku można było zauważyć wzrost zainteresowania tym państwem, co przekładało się na politykę wobec niego [Stępniewski 2011: 350]. W fazie początkowej zainteresowanie Gruzją wynikało z polityki demokratyzacji skierowanej do wszystkich państw powstałych po rozpadzie Związku Socjalistycznych Republik Radzieckich. Instrumentem mającym umożliwić stopniową demokratyzację tego obszaru była ustawa Freedom Support Act (FSA) z października 1992 roku [Stępniewski 2011: 350]. W ustawie zakładano pomoc państwom byłego Związku Radzieckiego w reformach prowadzących do demokratyzacji systemu politycznego oraz stworzenia wolnego rynku [SI: www.presidency.ucsb.edu]. Pomoc na podstawie tejże ustawy była przekazywana głównie za pośrednictwem Amerykańskiej Agencji ds. Rozwoju Międzynarodowego (USAID) oraz Agencji Informacyjnej Stanów Zjednoczonych (USIA) do czasu jej likwidacji w 1999 roku [Nye 2007: 141], ale również przez Ministerstwa Skarbu, Rolnictwa, Energetyki [Nye 2007: 29-95]. Opiewała ona na 1,611 mld dolarów w latach 1992-2004 oraz 420 mln dolarów w latach 2005-2009 (nie wliczając pakietu przyznanego na odbudowę Gruzji po wojnie z Rosją w sierpniu 2009 roku) [SI: www.state.gov]. Stany Zjednoczone Ameryki były największym dawcą pomocy bilateralnej dla Gruzji. Jeśli wziąć pod uwagę wielkość terytorium Gruzji, to należy uznać tę pomoc za bardzo znaczącą. Stany Zjednoczone Ameryki przyczyniły się również do wsparcia Gruzji za pośrednictwem Międzynarodowego Funduszu Walutowego oraz Banku Światowego.

Tabela 2 jest zestawieniem środków przeznaczonych przez Stany Zjednoczone Ameryki dla państw Kaukazu Południowego w latach 1992-2009 w milionach dolarów (dla porównania podano również wysokość środków przekazanych dla Armenii oraz Azerbejdżanu). Podane wartości środków nie obejmują pomocy przyznanej Gruzji po wojnie z Rosją w sierpniu 2008 roku.

Tabela 2. Pomoc bilateralna dla państw Kaukazu Południowego

\begin{tabular}{|l|c|c|c|c|c|c|}
\hline & $1992-2004$ & 2005 & 2006 & 2007 & 2008 & 2009 \\
\hline Armenia & 1581,09 & 91,01 & 81,70 & 58,14 & 62,38 & 27,90 \\
\hline Azerbejdżan & 588,72 & 79,15 & 47,94 & 40,12 & 26,34 & 24,70 \\
\hline Gruzja & 1611,17 & 126,87 & 86,01 & 75,84 & 64,30 & 67,05 \\
\hline Suma & 3780,98 & 297,03 & 215,65 & 174,1 & 153,02 & 119,65 \\
\hline
\end{tabular}

Źródło: Pliszczyńska, O. 2010. Polityka ,niebezpieczeństwa” Gruzji, Instytut Europy Środkowo-Wschodniej, Lublin, s. 34 . 
W styczniu 2004 roku Kongres Stanów Zjednoczonych Ameryki zatwierdził nowy program pomocy globalnej „Millenium Challenge Account” (MCA) [SI: www.mcc.gov]. Powołana Korporacja Wyzwania Milenijnego zawarła w sierpniu 2005 roku z Gruzją pięcioletnią umowę, opiewającą na 295,3 mln dolarów. Pieniądze te zostały przeznaczone na modernizację gazociągu, przebudowę drogi w regionie Samcche-Dżawachetii, fundusz wspierania drobnej przedsiębiorczości, modernizację infrastruktury oraz granty rolnicze.

W wyniku wojny gruzińsko-rosyjskiej w sierpniu 2008 roku prezydent Stanów Zjednoczonych Ameryki George W. Bush ogłosił przyznanie Gruzji dwuletniego pakietu pomocowego w wysokości 1 mld dolarów na odbudowę państwa. Kongres zatwierdził pakiet 23 września 2008 roku w Izbie Reprezentantów, a 27 września w Senacie. Pierwsza transza w wysokości $570 \mathrm{mln}$ dolarów była dostępna do końca 2008 roku, a o drugiej fazie pomocy miała zadecydować nowa administracja (w listopadzie 2008 roku odbyły się wybory prezydenckie w Stanach Zjednoczonych Ameryki). Był to sygnał potwierdzający poparcie dla Gruzji w wojnie z Rosją. Od 1998 roku Gruzja utrzymywała się w czołówce państw-beneficjentów pomocy ekonomicznej Stanów Zjednoczonych Ameryki. W 2006 roku pomoc ta wyniosła więcej niż pomoc dla Izraela, który tradycyjnie od 1950 roku był w czołówce państw-beneficjentów [Pliszczyńska 2010: 35-37]. Gruzja po uzyskaniu niepodległości nie kryła, że jednym z głównych celów polityki zagranicznej jest integracja z Sojuszem Północnoatlantyckim. W kwietniu 1994 roku przystąpiła do programu „Partnerstwo dla Pokoju”. Do głównych celów programu należy: zwalczanie zagrożeń (terroryzm międzynarodowy, profilerancja broni masowego rażenia), przeciwdziałanie rozszerzaniu wpływów Rosji na obszarze Gruzji i Azerbejdżanu oraz zapewnienie dostępu do węglowodorów z regionu Morza Kaspijskiego [Stępniewski 2011: 351]. W tym celu w 1995 roku opracowano „Indywidualny Program Partnerstwa NATO-Gruzja", odnoszący się do współpracy wojskowej obu stron. Następnie w 1996 roku jednostki wojskowe Gruzji brały udział w ćwiczeniach Sojuszu Północnoatlantyckiego.

W związku z ewolucją koncepcji strategicznej Stanów Zjednoczonych Ameryki oraz Sojuszu Północnoatlantyckiego po rozpadzie Związku Socjalistycznych Republik Radzieckich oraz rozszerzeniu Sojuszu na Wschód w 1999 roku, integracja Gruzji stawała się coraz ważniejszym elementem nowej misji Sojuszu - zapewnienie bezpieczeństwa w międzynarodowym otoczeniu państw członkowskich [Pliszczyńska 2010: 44]. W kwietniu 1999 roku na szczycie waszyngtońskim przyjęto nową koncepcję Sojuszu, która wyszła poza tradycyjne funkcje obrony. Ogłoszono „politykę otwartych drzwi” przez wprowadzanie odpowiedniego instrumentu - „Planu Działań dla Członkostwa” (MAP). Zgodnie z nim każde państwo chcące przystąpić do Sojuszu Północnoatlantyckiego mogło to zrobić po spełnieniu określonych warunków. W latach 1997-1998 Javier Solana, ówczesny sekretarz generalny Sojuszu, złożył kilka wizyt w państwach Zakaukazia. Jego wypowiedź, w której stwierdził, że Europa nie może być w pełni bezpieczna, jeśli nie będą uwzględniane państwa 
Kaukazu i Azji Centralnej [Howard 2014: 151-155, 166-167], stanowily potwierdzenie dla Gruzji, że drzwi do Sojuszu są dla niej otwarte.

Przełomowym momentem we współpracy na płaszczyźnie bezpieczeństwa między Gruzją a Stanami Zjednoczonymi Ameryki były zamachy terrorystyczne z 11 września 2001 roku. W wyniku tych ataków pozycja Gruzji w polityce Stanów Zjednoczonych Ameryki diametralnie wzrosła. Duże znaczenie miało położenie geopolityczne Gruzji, która mogła pełnić rolę korytarza tranzytowego dla walki z terrorystami pochodzącymi z Bliskiego Wschodu. Jako przejaw solidaryzmu w walce z terroryzmem, Gruzja udostępniła amerykańskiemu lotnictwu swoje bazy wojskowe. W maju 2002 roku została włączona do programu „Train and Equip” („Wyszkolić i wyposażyć"). Na podstawie tego programu szkolono gruzińską armię oraz dostarczono jej sprzęt o wartości $64 \mathrm{mln}$ dolarów (następnie zwiększono pomoc do $76 \mathrm{mln}$ dolarów). Przekazana pomoc miała na celu wsparcie Gruzji w walce z terroryzmem. Szczególnie istotny był problem czeczeńskich uchodźców osiadłych w Wąwozie Pankisi. Środki przekazane przez rząd Stanów Zjednoczonych Ameryki miały zapewnić Gruzinom możliwość utrzymania pokoju na terenie wąwozu i nie dopuścić do interwencji zbrojnej przez wojska rosyjskie (rząd Rosji na przestrzeni wielu lat po rozpoczęciu II wojny czeczeńskiej przekonywał, że Gruzja zapewnia schronienie czeczeńskim bojownikom) [Cecire 2013: 67].

Od 1999 roku Gruzja jako sojusznik Stanów Zjednoczonych Ameryki brała udział w misji Sojuszu Północnoatlantyckiego w Kosowie (do zakończenia w 2008 roku), a w 2003 roku wysłała do Iraku 850 żołnierzy [SI: www.mod.gov.ge]. We wrześniu 2004 roku Górski Batalion, który był szkolony w ramach programu „Train and Equip” został wysłany do Afganistanu na ponadtrzymiesięczną misję [SI: www.civil.ge]. W 2002 roku na szczycie Sojuszu Północnoatlantyckiego w Pradze prezydent Szewardnadze oficjalnie wystąpił o przyjęcie Gruzji do Sojuszu [Trzaskowski 2009: 135]. Na tymże szczycie utworzono nowy instrument - „Individual Partnership Action Plan” (IPAP). 29 października 2004 roku Gruzja jako pierwsze państwo podpisała umowę „Indywidualnego Planu Działania na rzecz Partnerstwa” [Stępniewski 2011: 353]. Przyznanie Gruzji „Indywidualnego Planu Działania na rzecz Partnerstwa" umożliwiło przeprowadzenie wielu ważnych reform w państwie. Opracowano pierwszą Strategię Bezpieczeństwa Narodowego [SI: www.parliament. ge] i Narodową Strategię Wojskową [SI: www.mod.gov.ge], zreformowano policję i wojsko w celu utworzenia nowoczesnych służb. Sektor bezpieczeństwa przeszedł reformy w kierunku zgodności ze standardami państwa prawa. W 2005 roku Stany Zjednoczone Ameryki przeznaczyły $53 \mathrm{mln}$ na reformę wojsk gruzińskich. Największa pomoc była kierowana przez „Georgia Border Security and Law Enforcement Assistance Program” [SI: www.mod.gov.ge]. We wrześniu 2006 roku Sojusz Północnoatlantycki zatwierdził aplikację Gruzji przystąpienia do formuły Intensywnego Dialogu, wskazując na postęp w reformach.

Szczyt Sojuszu w Bukareszcie w kwietniu 2008 roku miał być dla Gruzji zwieńczeniem wieloletnich działań na rzecz integracji ze strukturami euroatlantyckimi. 
Jednak w wyniku zdecydowanie negatywnej postawy Niemiec i Francji wobec przyznania Gruzji „Planu Działań na rzecz Członkostwa” szczyt w Bukareszcie okazał się porażką [SI: www.mod.gov]. Decyzja ta pokazała, jak w ówczesnym czasie był spolaryzowany Sojusz od środka. Gruzinów wsparły Stany Zjednoczone Ameryki, Polska oraz państwa bałtyckie, których głównym celem było zapewnienie bezpieczeństwa Gruzji ze strony Federacji Rosyjskiej oraz umożliwienie dalszych reform wewnętrznych. Zarówno Francja, jak i Niemcy kierowały się troską o własne powiązania ekonomiczne z Federacją Rosyjską. O ile kanclerz Niemiec Angela Merkel argumentowała odmowę przyznania „Planu na rzecz Członkostwa” Gruzji brakiem spełnienia wymogów odnoszących się do integralności terytorium państwa (kwestia separatyzmu Abchazji i Osetii Południowej), o tyle Francja zajęła zdecydowane stanowisko w kwestii Gruzji, oświadczając, że Sojusz Północnoatlantycki powinien dążyć do wzmacniania stosunków z Rosją, a udzielenie „Planu na rzecz Członkostwa” państwu „bliskiej zagranicy” spowoduje niepotrzebne pogorszenie tych stosunków. Gruzja otrzymała jedynie zapewnienie, że droga do Sojuszu jest otwarta.

Pod koniec października 2008 roku wizytę w Gruzji złożył zastępca asystenta sekretarza stanu Stanów Zjednoczonych Ameryki ds. Eurazji Daniel Fried. Po raz kolejny zapewnił o poparciu dla jej przyjęcia do struktur Sojuszu [SI: www.osw.waw.pl]. W styczniu 2009 roku sekretarz stanu Stanów Zjednoczonych Ameryki Condoleezza Rice oraz minister spraw zagranicznych Gruzji Grigol Vashadze podpisali w Waszyngtonie bilateralny układ o strategicznym partnerstwie, w którym określono stosunki amerykańsko-gruzińskie jako „oparte na tych samych wartościach i wspólnym interesie". W dokumencie tym znajdują się informacje o zasadach partnerstwa, współpracy w zakresie bezpieczeństwa i obrony, w której jest mowa o rozwijaniu współpracy z Sojuszem Północnoatlantyckim oraz o potencjale Gruzji jako państwa przyczyniającego się do bezpieczeństwa światowego, czego dowiodła pomoc wojsk gruzińskich w Iraku [Pliszczyńska 2009: 48].

\section{ZAKOŃCZENIE}

Historia bezpośrednich stosunków między Gruzją a Stanami Zjednoczonymi Ameryki jest krótka, aczkolwiek bardzo intensywna. To zjawisko jest wynikiem aspiracji euroatlantyckich Gruzji oraz świadomości potrzeby bezpieczeństwa, które daje Gruzji Waszyngton. Pomoc finansowa przekazywana od lat 90. ubiegłego stulecia rządowi w Tbilisi na modernizację państwa oraz jego instytucji świadczy o tym, że nie było i nie jest to tylko deklarowane wsparcie. Podpisanie w 2009 roku układu o partnerstwie strategicznym było aktem wieńczącym wieloletnią współpracę, a także zapewnieniem dalszego wsparcia w rozwoju państwa i docenieniem aspiracji członkowskich Gruzji do Sojuszu Północnoatlantyckiego. Od rozpoczęcia urzędowania przez Baracka Obamę było widoczne ograniczenie zainteresowania obszarem Kaukazu Południowego, w tym Gruzji. Było to spowodowane „resetem” w stosun- 
kach Stany Zjednoczone Ameryki-Rosja, który był celem administracji nowego prezydenta. Jednym z założeń owego „resetu” było zobowiązanie Waszyngtonu do rezygnacji z promowania rozszerzenia Sojuszu Północnoatlantyckiego na obszarze Wspólnoty Niepodległych Państw. Stany Zjednoczone Ameryki ograniczyły się do retorycznego popierania polityki „otwartych drzwi”, która była jednak pustym zobowiązaniem wzmocnionym sprzeciwem państw europejskich [Kaczmarski 2011: 10]. Wraz z odejściem od władzy George’a Busha ucichły uczucia wdzięczności wobec Szewardnadzego i jego udziału w zakończeniu ,zimnej wojny”, które miały znaczący wpływ na kształtowanie stosunków bilateralnych na początku lat 90. XX wieku. Również bliskie stosunki pracowników administracji Saakaszwilego i ustępującego prezydenta Stanów Zjednoczonych Ameryki przestały działać, w wyniku czego Gruzja straciła możliwość nacisku na administrację w Waszyngtonie.

Istotną kwestią w ograniczeniu pomocy finansowej dla Gruzji na początku prezydentury Obamy była sytuacja wewnętrzna w Stanach Zjednoczonych Ameryki. Obama przez ograniczenie zobowiązań zagranicznych chciał poprawić opiekę zdrowotną oraz w dobie kryzysu światowego wzmocnić konkurencyjność gospodarczą Stanów Zjednoczonych Ameryki. Podpisanie układu o strategicznym partnerstwie było jednym z niewielu istotnych gestów dyplomatycznych wobec Gruzji w trakcie trwania pierwszej kadencji Obamy. Pierwsze spotkanie prezydenta Stanów Zjednoczonych Ameryki z prezydentem Saakaszwilim odbyło się dopiero 19 listopada 2010 roku na szycie Sojuszu Północnoatlantyckiego w Lizbonie. Spotkanie prezydentów było poświęcone „dalszemu umacnianiu stosunków bilateralnych i zwiększeniu poziomu współpracy". W trakcie spotkania Obama podziękował Gruzji za znaczące zaangażowanie w Afganistanie i wyraził nadzieję na zacieśnianie współpracy [SI: www.osw.waw.pl]. W 2013 roku Millenium Challenge Account zatwierdził program „Georgia Compact II”, w którym zakładano przyznanie Gruzji pomocy finansowej w wysokości 140 milionów dolarów m.in. na rozwój nauki i technologii oraz podniesienie jakości kształcenia studentów [SI: www.mcc.gov].

Dużym wyzwaniem dla polityki zagranicznej Stanów Zjednoczonych Ameryki wobec obszaru postradzieckiego, w tym Gruzji, okazał się kryzys ukraiński na przełomie 2013-2014 roku oraz „doktryna Putina” [Menkiszak 2014: 4], w której założono m.in. prawo Rosji do wpływania na politykę państw byłego Związku Radzieckiego. W przypadku Gruzji doktryna ta implikuje wysokie zagrożenie użycia siły militarnej w celu zdestabilizowania państwa i niedopuszczenia do integracji ze strukturami zachodnimi, jak miało to miejsce w 2008 roku. Prezydent Władimir Putin odbiera tym samym prawo państwom postradzieckim do integracji ze strukturami zachodnimi, argumentując ów sprzeciw zapewnieniem bezpieczeństwa Rosji. 


\section{BIBLIOGRAFIA}

About MCC, https://www.mcc.gov/about (dostęp: 4.05.2015).

Baran, Z. 2005. The Baku-Tbilisi-Ceyhan Pipeline: Implications for Turkey, Central Asia-Caucasus Institute, Waszyngton.

Bałon, K. 2001. Co to jest partnerstwo strategiczne?, „Biuletyn Polskiego Instytutu Spraw Międzynarodowych", nr 34 .

Burant, R.S. 2000. Stosunki polsko-ukraińskie a idea strategicznego partnerstwa, Fundacja Wspomagania Wsi.

Cecire, M.H. 2013. Security and Symbolism: Georgia's NATO Aspirations in Perspective, [w:] Georgian Foreign Policy: The Quest for Sustainable Security, K. Kakachia, M. Cecire (red.), Konrad-Adenauer-Stiftung, Tbilisi.

Coppieters, B. 1998. Georgia in Europe: The Idea of a Periphery in International Relations, [w:] Commonwealth and independence in post-Soviet Eurasia, B. Coppieters, A. Zverev, D. Trenin (red.), Wydawnictwo Frank Cass Publishers, Portland.

Georgia Compact II, https://www.mcc.gov/where-we-work/program/georgia-compact-ii (dostęp: 4.05.2015).

Georgia Monitoring Project: Review of U.S. Assistance in the Post-Conflict Area of Shida Kartli, Georgia, http://www.state.gov/p/eur/ace/gmp/193477.htm (dostęp: 21.01.2014).

Georgia Sends Troops to Afghanistan, http://www.civil.ge/eng/article.php?id=7710 (dostęp: 16.03.2015).

Gruzja: pierwsze spotkanie Obama-Saakaszwili, http://www.osw.waw.pl/pl/publikacje/analizy/2010-11-24/ gruzja-pierwsze-spotkanie-obama-saakaszwili (dostęp: 21.01.2014).

Howard, G. 1998. NATO and The Caucasus: The Caspian Axis, [w:] NATO After Enlargement: New Challenges, New Missions, New Forces, S. Blank (red.), Strategic Studies Institute, Carlisle.

International Missions, https://mod.gov.ge/p/ISAF (dostęp: 17.03.2015).

Kaczmarski, M. 2011. Kruchy „RESET”. Bilans i perspektywy przemian w relacjach rosyjsko-amerykańskich, Ośrodek Studiów Wschodnich, Warszawa.

Menkiszak, M. 2014. Doktryna Putina: Tworzenie koncepcyjnych podstaw rosyjskiej dominacji na obszarze postradzieckim, Ośrodek Studiów Wschodnich, Warszawa.

Materski, W. 2010. Gruzja, Wydawnictwo Trio, Warszawa.

National Military Strategy, https://mod.gov.ge/assets/up-modul/uploads/pdf/NMS-ENG.pdf (dostęp: 4.05.2015)

National Security Concept of Georgia http://www.parliament.ge/files/292_880_927746_concept_en.pdf (dostęp: 19.04.2015).

McFarlane, N.S. 2013. The Reluctant Patron: Georgia-U.S. Relations, [w:] Georgian Foreign Policy: The Quest for Sustainable Security, K. Kakachia, M. Cecire (red.), Konrad-Adenauer-Stiftung, Tbilisi.

Nye, J. 2007. Soft Power: Jak osiagną́ sukces w polityce światowej, Wydawnictwa Akademickie i Profesjonalne, Warszawa.

Pliszczyńska, O. 2010. Polityka „niebezpieczeństwa” Gruzji, Instytut Europy Środkowo-Wschodniej, Lublin.

Saakashvili Inaugurated As President, http://www.rferl.org/content/article/1051322.html (dostęp: 16.03.2015).

Statement by President of Georgia Eduard Szewardnadze at the EAPC Summit, http://www.nato.int/docu/ speech/2002/s021122h.htm (dostęp: 21.01.2014).

Statement on Signing the FREEDOM Support Act, http://www.presidency.ucsb.edu/ws/?pid=21658 (dostęp: 4.05.2015).

Stępniewski, T. 2011. Geopolityka regionu Morza Czarnego w pozimnowojennym świecie, Instytut Europy Środkowo-Wschodniej, Lublin-Warszawa.

Strachota, K., Bartuzi, W. 2008. Reintegracja czy rekonkwista? Gruzja wobec Abchazji i Osetii Poludniowej w kontekśsie uwarunkowań wewnętrznych i międzynarodowych, Ośrodek Studiów Wschodnich, Warszawa. 
The geopolitics of Pipeline diplomacy, http://www.isn.ethz.ch/Digital-Library/Articles/Special-Feature/ Redirect/?id=153580\&lng=en (dostęp: 27.04.2015).

Trzaskowski, P. 2009. Gruzińska ,,rewolucja róż”. Zachód i idea zachodu a przemiany polityczne w Gruzji, Fundacja Studiów Międzynarodowych, Warszawa.

United States - Georgia Charter on Strategic Partnership, http://www.state.gov/p/eur/rls/or/121029.htm (dostęp: 28.04.2015).

U.S. - Georgia Strategic Partnership Commision, http:/www.state.gov/p/eur/ci/gg/usgeorgiacommission/ index.htm (dostęp: 21.01.2014).

Welt, C. 2010. How Strategic is the US-Georgia Strategic Partnership?, George Washington University, Washington.

\section{STRATEGIC PARTNERSHIP BETWEEN GEORGIA \\ AND THE UNITED STATES OF AMERICA IN 1992-2009}

Abstract: The article presents relations between Georgia and the United States of America in the years 1992-2009. Time frames were not selected randomly and represent the establishment of bilateral relations between states on 23 April 1992 and the signing of strategic partnership agreement on 9 January 2009. United States interest in Georgia was due to a policy of diversification of energy resources of the Caspian Sea within the boundaries of Azerbaijan. In diversification plans, Georgia was to be a transit area for oil and gas to Western Europe. Position of Georgia was reinforced by the intention to avoid the territory of the Russian Federation, and the Armenian direction was impossible because the Azerbaijani-Armenian conflict over Nagorno-Karabakh. The United States supported Georgia's aspirations for membership in NATO and the European Union allocating significant financial assistance and support for administrative reform, economic and government.

Keywords: Georgia, the United States of America, international relations, foreign policy

BIOGRAM

Bartosz Janik, student pierwszego roku III stopnia Nauk o polityce na Wydziale Politologii Uniwersytetu Marii Curie-Skłodowskiej w Lublinie. Zainteresowania badawcze autora to polityka wschodnia II i III RP, współczesne stosunki polsko-rosyjskie oraz geopolityka obszaru poradzieckiego. Kontakt e-mail: bartosz.janik225@gmail.com. 